\title{
UMORZENIE POSTECPOWANIA KARNEGO W TRYBIE ART. 62A \\ USTAWY Z DNIA 29 LIPCA 2005 R. O PRZECIWDZIALANIU NARKOMANII JAKO POZYTYWNY ŚRODEK REAKCJI KARNOPRAWNEJ STOSOWANY WOBEC SPRAWCÓW POSIADAJĄCYCH NARKOTYKI MIĘKKIE W NIEZNACZNEJ ILOŚCI I PRZEZNACZONE NA WLASNY UŻYTEK
}

\begin{abstract}
Streszczenie. Ustawą nowelizacyjną z dnia 1 kwietnia 2011 r. wprowadzono do ustawy art. 62a umożliwiający umorzenie postępowania karnego jeszcze przed wydaniem postanowienia o wszczęciu śledztwa lub dochodzenia wobec sprawcy przestępstwa posiadania substancji psychotropowej lub środków odurzających, w tym także w wypadku mniejszej wagi (art. 62 ust. 1 i ust. 3 ustawy). Warunkiem koniecznym jest ustalenie, iż orzeczenie kary byłoby niecelowe ze względu na okoliczności popełnienia czynu, a także stopień jego społecznej szkodliwości, nadto podejrzewany posiadane środki odurzające lub substancje psychotropowe musi mieć w ilości nieznacznej i przeznaczone tylko na własny użytek. Artykuł omawia kwestie prawne wyżej opisanej instytucji, która wprowadziła możliwość depenalizacji zakresu odpowiedzialności karnej sprawcy - posiadacza narkotyków. Podjęto także próbę oceny skutków dodania art. 62a do ustawy poprzez analizę danych statystycznych, obrazujących zastosowanie tej instytucji przez prokuraturę i sąd karny w praktyce orzeczniczej.
\end{abstract}

Słowa kluczowe: narkomania, umorzenie postępowania, sankcja karna, postępowanie przygotowawcze i jurysdykcyjne.

\section{WPROWADZENIE}

W aktualnym stanie prawnym w Polsce aktem prawa powszechnie obowiązującego najpełniej regulującym problematykę narkomanii jest ustawa z dnia 29 lipca 2005 r. o przeciwdziałaniu narkomanii. Rozdział 7 ustawy zawiera przepisy karne i normuje zasady odpowiedzialności karnej sprawców przestępstw stypizowanych w tym rozdziale.

Przestępczość narkotykowa jest w Polsce zjawiskiem powszechnym i stanowi poważny problem społeczny. Ponadto stanowi bardzo poważne zagrożenie zarówno dla zdrowia, jak i życia osób uzależnionych od środków odurzających

\footnotetext{
* Uniwersytet Gdański, Wydział Prawa i Administracji, Katedra Prawa Karnego Materialnego i Kryminologii, Zakład Kryminologii, adrianbartha@gmail.com.
} 
czy substancji psychotropowych. Niesie także szereg zagrożeń dla całego społeczeństwa, generując bardzo wysokie koszty społeczne, jak też finansowe związane z przeciwdziałaniem jej skutkom. Samo prowadzenie postępowania przygotowawczego wymaga angażowania znacznych sił i środków organów ścigania, jak choćby powołania biegłego (najczęściej laboratorium kryminalistyczne działające przy Komendach Wojewódzkich Policji), celem poddania ujawnionych substancji analizie chemiczno-toksykologicznej.

Powyższy mechanizm postępowania, począwszy od noweli z dnia 26 października 2000 r. uprzedniej ustawy o przeciwdziałaniu narkomanii, stosowany był wobec każdego sprawcy posiadającego środki odurzające bądź substancje psychotropowe bez względu na ilość substancji zabronionej oraz bez względu na przeznaczenie tychże substancji.

Dopiero zmiana dotychczas obowiązującej ustawy o przeciwdziałaniu narkomanii, która weszła w życie 9 grudnia 2011 r., ustanawiająca art. 62a, wprowadziła rozwiązanie umożliwiające umorzenie postępowania (jeszcze przed jego formalnym wszczęciem w drodze postanowienia), co w konsekwencji dla potencjalnego sprawcy - posiadającego narkotyki w nieznacznej ilości i przeznaczone na własny użytek - będzie oznaczało brak wymierzenia kary kryminalnej.

Niniejsze opracowanie omawia kwestie prawne wyżej opisanej instytucji, która wprowadziła możliwość depenalizacji zakresu odpowiedzialności karnej sprawcy - posiadacza narkotyków. Podjęto także próbę oceny skutków dodania art. 62a do ustawy poprzez analizę danych statycznych, obrazującą zastosowanie tej instytucji przez prokuraturę i sąd karny w praktyce orzeczniczej. Jednocześnie celem jest wykazać, iż instytucja umorzenia postępowania wobec osoby posiadającej nieznaczne ilości narkotyków przeznaczonych na cele konsumenckie była co do zasady trafnym rozwiązaniem legislacyjnym, usprawniającym procedowanie sądów oraz organów ścigania dzięki umożliwieniu zwłaszcza tym ostatnim skoncentrowania uwagi i środków, a w konsekwencji zwiększenia wykrywalności przestępczości narkotykowej o znacznie większym ciężarze gatunkowym.

\section{PROBLEMATYKA NARKOMANII W POLSCE}

Kwestię problemu narkomanii w Polsce rozumianej sensu largo obrazują dane statystyczne osób skazanych zaprezentowane w tabeli 1 .

Dla zobrazowania wielkości przedstawionych danych liczbowych można wskazać, iż w roku 2008 r. osób skazanych z przepisów ustawy o przeciwdziałaniu narkomanii było niemalże tyle samo, ile osób zamieszkuje Aleksandrów Łódzki. Według danych z 31 grudnia 2008 miasto liczyło 20684 mieszkańców (Nowak, Stańczyk, Znajewska 2009, 66), zaś liczba osób skazanych była zaledwie o 210 mniejsza. 
Prawomocnie skazani dorośli (w liczbach bezwzględnych) według rodzaju czynu ${ }^{a}$

\begin{tabular}{|l|c|c|c|}
\hline Rok & $\begin{array}{c}\text { Liczba osób } \\
\text { skazanych ogółem }\end{array}$ & $\begin{array}{c}\text { Liczba skazanych z ustawy z dnia 29 lipca } \\
\text { 2005 r. o przeciwdziałaniu narkomanii }\end{array}$ & $\begin{array}{c}\text { Liczba skazanych } \\
\text { z art. 62 ust. 1-3 }\end{array}$ \\
\hline 2006 & 462937 & $19652(4,25 \%)$ & $12915(65,72 \%)$ \\
\hline 2007 & 426377 & $20639(4,84 \%)$ & $14206(68,83 \%)$ \\
\hline 2008 & 420729 & $20474(4,87 \%)$ & $13483(65,85 \%)$ \\
\hline 2009 & 415272 & $19928(4,79 \%)$ & $13023(65,36 \%)$ \\
\hline 2010 & 432891 & $20559(4,75 \%)$ & $13033(63,93 \%)$ \\
\hline 2011 & 423464 & $19629(4,64 \%)$ & $12451(63,43 \%)$ \\
\hline 2012 & 408107 & $17614(4,32 \%)$ & $11665(66,23 \%)$ \\
\hline 2013 & 353208 & $18096(5,12 \%)$ & $11283(62,36 \%)$ \\
\hline 2014 & 293852 & $17386(5,92 \%)$ & $11214(64,50 \%)$ \\
\hline
\end{tabular}

Objaśnienia:

${ }^{a} \mathrm{~W}$ kolumnie trzeciej (od lewej) wartość \% odniesiono do liczby osób skazanych ogólnie, zaś w kolumnie czwartej wartość \% odniesiono do liczby osób skazanych za czyny z ustawy o przeciwdziałaniu narkomanii.

Źródło: opracowanie własne na podstawie danych statystycznych Ministerstwa Sprawiedliwości oraz roczników statycznych GUS, a także obliczeń własnych.

Powyższy okres statystyczny dotyczy lat 2006-2014, albowiem ustawa o przeciwdziałaniu narkomanii z dnia 29 lipca 2005 r. weszła w życie z dniem 4 października 2005 r., zastępując ustawę z dnia 24 kwietnia 1997 r. o przeciwdziałaniu narkomanii. W tabeli dodatkowo przedstawiono (kolumna czwarta) liczbę osób skazanych tylko z art. $62 \mathrm{NarkU}$, a więc za przestępstwa posiadania środków narkotycznych, albowiem w odniesieniu do skazań z pozostałych przepisów Rozdziału 7 NarkU występują one najliczniej (w przedziale 62-68\%).

\section{PRZESTĘPSTWO POSIADANIA - ART. 62 USTAWY}

W przestępstwie nielegalnego, gdyż niezgodnego z przepisami ustawy, posiadania środków odurzających, czy substancji psychotropowych, ujętych kolejno w załącznikach 1 i 2 NarkU, ustawodawca wyróżnił trzy typy:

1. Typ podstawowy (art. 62 ust. 1),

2. Typ kwalifikowany (art. 62 ust. 2), wskazując na znamię znacznej ilości środków odurzających lub substancji psychotropowych, 
3. Typ uprzywilejowany (art. 62 ust. 3), tzw. wypadek mniejszej wagi (Krajewski 1998, 27).

Ustawa nie ustaliła sztywnego kryterium, jaka ilość substancji niedozwolonej spełnia jedno z powyższych kryteriów, np. w załączniku ustawy. Wydaje się to zasadne przy tak zróżnicowanym i zmieniającym się wachlarzu środków odurzających i substancji psychotropowych (czego wyrazem może być nagłaśniana przez media „walka z dopalaczami” (Ożóg 2012, 337). Sama ustawa wraz z załącznikami od wejścia w życie nowelizowana była już dwadzieścia razy. Kwalifikacja czynu zabronionego z art. 62 NarkU ma w związku z tym charakter ocenny i przez to jest bardziej racjonalna. Zauważyć należy, że w praktyce orzeczniczej w obszarze interpretacji tego znamienia wypracowano na przestrzeni ostatnich lat obowiązywania ustawy o przeciwdziałaniu narkomanii akceptowalne mierniki (Muszyńska 2010, 4), co więcej dotyczące zarówno ustawy uprzednio obowiązującej z 1997 r., jak i obecnie obowiązującej z 2005 r.

Mając na uwadze przyjęte $\mathrm{w}$ ustawie powyższe kryteria rozwarstwiania przestępstw, należy dostosować je do sytuacji faktycznych, z jakimi stykamy się w rzeczywistości społecznej łączącej się z nielegalnymi czynami w tzw. „branży narkotykowej”. Otóż w pełni uzasadnione jest przyjęcie, że:

- ilość nieznaczna to jedna, dwie lub trzy porcje (dawki),

- ilość mala to kilka porcji,

- ilość przeciętna to kilkanaście czy też kilkadziesiąt porcji,

- ilość znaczna to kilkaset, kilka tysięcy i więcej porcji, co wskazuje na uprawianie nielegalnego procederu związanego ze środkami odurzającymi, psychotropowymi itp. na szerszą skalę (Konarska-Wrzosek 1999, 114) - popularnie określanego mianem „dilerka”.

W tabeli 2 zobrazowano liczbę osób skazanych za poszczególne typy przestępstwa posiadania substancji niedozwolonych w rozumieniu art. 62 NarkU.

Uwzględniając ujęcie procentowe liczby osób skazanych w tzw. wypadku mniejszej wagi, dane liczbowe wskazują, że co piąty skazany to sprawca przestępstwa z art. 62 ust. 3 NarkU (ok. 20\%). Nadto zwiększeniu o połowę uległa liczba osób skazanych za posiadanie znacznej ilości środków narkotycznych, z 4\% aż do 9,43\%. Powyższe prowadzi do konkluzji, iż podleganie karalności za posiadanie jakiejkolwiek ilości substancji zabronionej przez ustawę o przeciwdziałaniu narkomanii powoduje, że wyroki skazujące (w tym także warunkowo umarzające postępowanie karne) wydawane są wobec „płotek”, a „rekiny”, których liczba podwoiła się (i mowa tu o przestępstwach wykrytych), czyli sprawcy trudniejsi do rozpracowania i odłowienia, nie muszą znaleźć się w kręgu zainteresowania prokuratury i policji (Płatek 2011, 10). Wykrywalność przestępstw w ujęciu statystycznym będzie niezmienna, a niewątpliwie organom ścigania łatwiej ująć sprawców przestępstw mniejszej wagi niż tych, wobec których górna granica ustawowego zagrożenia karą wynosi 10 lat, a więc osoby prawdopodobnie uza- 
leżnione od środków odurzających czy substancji psychotropowych, bądź używające szkodliwie substancji psychoaktywnej ${ }^{1}$, względnie wobec których zachodzi uzasadnione podejrzenie rozpowszechniania substancji niedozwolonych, jeśli uwzględnić znamię znacznej ilości.

Tabela 2

Prawomocnie skazani dorośli (w liczbach bezwzględnych) według rodzaju czynu

\begin{tabular}{|c|c|c|c|}
\hline Rok & $\begin{array}{c}\text { Liczba osób skazanych } \\
\text { z art. 62 ust. 1 }\end{array}$ & $\begin{array}{c}\text { Liczba osób skazanych } \\
\text { z art. 62 ust. 2 }\end{array}$ & $\begin{array}{c}\text { Liczba osób skazanych } \\
\text { z art. 62 ust. 3 }\end{array}$ \\
\hline 2006 & $9666(74,84 \%)$ & $515(4 \%)$ & $2734(21,16 \%)$ \\
\hline 2007 & $10448(73,55 \%)$ & $588(4,14 \%)$ & $3170(22,31 \%)$ \\
\hline 2008 & $10018(73,30 \%)$ & $619(5,59 \%)$ & $2846(21,11 \%)$ \\
\hline 2009 & $9835(75,52 \%)$ & $670(5,14 \%)$ & $2518(19,34 \%)$ \\
\hline 2010 & $9638(73,95 \%)$ & $772(5,92 \%)$ & $2623(20,13 \%)$ \\
\hline 2011 & $9864(72,60 \%)$ & $900(6,62 \%)$ & $2824(20,78 \%)$ \\
\hline 2012 & $8507(72,93 \%)$ & $893(7,65 \%)$ & $2265(19,42 \%)$ \\
\hline 2013 & $8060(71,43 \%)$ & $1024(9,08 \%)$ & $2199(19,49 \%)$ \\
\hline 2014 & $7998(71,32 \%)$ & $1057(9,43 \%)$ & $2159(19,25 \%)$ \\
\hline
\end{tabular}

Źródło: opracowanie własne na podstawie danych statystycznych Ministerstwa Sprawiedliwości oraz Roczników statystycznych GUS, a także obliczeń własnych.

Jednocześnie na gruncie przepisów ustawy o przeciwdziałaniu narkomanii brakowało regulacji umożliwiającej odstąpienie od zasady legalizmu wobec sprawców niektórych czynów zabronionych. Penalizacji podlegało posiadanie jakiejkolwiek ilości środka odurzającego. Stan taki w Polsce obowiązuje od 2000 r., a więc rozpoczął się jeszcze pod rządami uprzedniej ustawy o przeciwdziałaniu narkomanii z 24 kwietnia 1997 r.

Pierwszą ustawową regulacją dotyczącą stricte problematyki narkomanii była ustawa z dnia 31 stycznia 1985 r. o zapobieganiu narkomanii, która obowiązywała od 1 marca 1985 r. Posiadanie narkotyków leżało poza zakresem unormowań prawnokarnych tego aktu prawnego. Tym samym polskie ustawodawstwo antynarkotykowe tworzyło podstawy dla modelu profilaktyczno-leczniczego podejścia do zjawiska narkomanii. Aczkolwiek tolerancyjny charakter ustawy

\footnotetext{
${ }^{1}$ Por. stanowisko Rady Ministrów wobec poselskiego projektu ustawy o zmianie ustawy o przeciwdziałaniu narkomanii (druk nr 244).
} 
z 1985 r. wynikał m.in. ze stosunkowo niskiego zagrożenia nielegalnym obrotem narkotykami - w porównaniu z sytuacją, jaka w latach osiemdziesiątych XX w. miała miejsce w Europie Zachodniej (Srogosz 2008, 426-432). Zmiany społeczno-gospodarcze po 1989 r., a w tym swoboda działalności gospodarczej, mające wpływ także na intensywny rozwój przestępczości narkotykowej, oraz ratyfikacja Konwencji o zwalczaniu nielegalnego obrotu (sporządzona w Wiedniu 20 grudnia 1988 r.) spowodowały, że w ustawie o przeciwdziałaniu narkomanii z 1997 r. nielegalne posiadanie środków odurzających i substancji psychotropowych objęto zakresem oddziaływania prawa karnego (art. 48 NarkU 1997). Ustawa z 1997 r. przewidywała jednakże brak karalności sprawców, którzy posiadali na własny użytek środki odurzające lub substancje psychotropowe w ilości nieznacznej (art. 48 ust. 4 NarkU $1997^{2}$ ). Sprawca taki w ogóle nie podlegał karze. Wspomnianą ustawą nowelizacyjną z dnia 26 października 2000 r. skreślono art. 48 ust. 4. W polskim ustawodawstwie antynarkotykowym nastąpił więc zwrot $w$ kierunku modelu restrykcyjno-represyjnego, w którym karze podlegają nie tylko zachowania tworzące podaż, ale także posiadanie narkotyków na własny użytek, czyli zachowania konsumenckie (Srogosz 2008, 428). Penalizacja jakiejkolwiek ilości substancji psychotropowych czy środków odurzających uzasadniana była okolicznością, iż zatrzymywani sprawcy posiadają przy sobie niewielkie ilości tych środków bądź substancji, a zapis art. 48 ust. 4 NarkU 1997 nie ułatwia walki z handlarzami i dealerami (Krajewski 2001, 448).

Po ponad 11 latach obowiązywania takiego stanu prawnego w uzasadnieniu ustawy nowelizacyjnej z dnia 1 kwietnia $2011 \mathrm{r}$. wprost stwierdzono, iż mimo zaostrzenia polityki karnej wobec narkomanii nie uzyskano wzrostu wykrywalności przestępstw związanych z tą kategorią. Restrykcyjność nie doprowadziła także do ograniczenia konsumpcji narkotyków w Polsce ani nie ograniczyła dostępności narkotyków, co potwierdziły m.in. badania Instytutu Psychiatrii i Neurologii przeprowadzone w Warszawie (Sierosławski 2008, 58-66). Wyprowadzono w nich wniosek, iż konsumenci narkotyków są ostatnim ogniwem procesu dystrybucji środków odurzających i ze względu na skuteczność działań wykrywczych najmniej interesującym służby ochrony porządku (organów ścigania). Osiągnięto efekt wręcz odwrotny, albowiem rozszerzenie zakresu penalizacji prowadziło do rozproszenia sił służb zwalczających tę kategorię przestępczości, które powinny koncentrować swoje działania na organizatorach handlu. W opinii Helsińskiej Fundacji Praw Człowieka (z dnia 22 lutego 2011 r.) problem ten zauważono i wskazano, iż nowelizacja ustawy o przeciwdziałaniu narkomanii z 2000 r. nie spełniła pokładanych w niej nadziei. Zauważenia wymaga, iż w teorii kryminologii wskazano, że praktyka radykalnego obostrzenia kar nie przynosi trwałych rezultatów, a jedynie efekty krótkotrwałe, a następnie sytuacja powraca do stanu

\footnotetext{
${ }^{2}$ Odnośnie do zgodności art. 48 ust. 4 NarkU 1997 z art. 3 ust. 2 Konwencji o zwalczaniu nielegalnego obrotu por. Krajewski 1997, 58-69.
} 
wyjściowego lub też prowadzi do efektów przeciwnych niż zamierzone (Lernell 1978, 333). Nadto wyniki badań empirycznych wskazują, że olbrzymia większość spraw o przestępstwa z art. 62 ust. 1 lub 2 NarkU dotyczy posiadania dwóch środków, a mianowicie amfetaminy lub marihuany, a znaczna ich część to sprawy drobne, a nawet niezwykle drobne (Krajewski 2008b, 31-45).

\section{UMORZENIE POSTĘPOWANIA „PRZED JEGO WSZCZECCIEM”} - ART. 62A USTAWY

Między innymi z powodów przytoczonych w punkcie 3 zdecydowano się na zmianę, dość daleko idącą, choć de facto w pewnym zakresie przywracającą regulacje z ustawy z 1997 r. - tj. wspomniany ust. 4 art. 48 NarkU 1997. Do aktualnie obowiązującej ustawy z 2005 r. o przeciwdziałaniu narkomanii dodano art. 62a, który przewiduje fakultatywne umorzenie postępowania karnego wobec sprawców posiadających nieznaczne ilości środków odurzających lub substancji psychotropowych przeznaczonych na własny użytek. Zmiana ta weszła w życie 9 grudnia 2011 r. W odróżnieniu jednak od art. 48 ust. 4 NarkU 1997, nie wyłącza karalności stypizowanego ustawą zachowania, a jedynie może prowadzić do umorzenia postępowania, choć dla sprawcy finalnym rozstrzygnięciem jest brak wymierzenia mu sankcji karnej.

Taki zapis ustawowy art. 62a NarkU spotkał się z dużą krytyką (Krajewski 2008a, 221-234). Jeszcze na etapie projektu tej ustawy Biuro Studiów i Analiz Sądu Najwyższego (przy piśmie z dnia 15 października 2010 r. do druku nr 3420) wyraziło swoją dezaprobatę, wskazując przede wszystkim na sprzeczność z przepisami kpk, a w szczególności art. 303, który stanowił, że ,jeżeli zachodzi uzasadnione podejrzenie popełnienia przestępstwa, wydaje się z urzędu lub na skutek zawiadomienia o przestępstwie postanowienie o wszczęciu śledztwa". Innymi słowy, w świetle kpk przed wszczęciem śledztwa czy dochodzenia nie może dojść do umorzenia postępowania karnego. Postępowanie bowiem takie na etapie postępowania przygotowawczego prowadzi się właśnie w formie śledztwa lub dochodzenia. Samo semantyczne ujęcie sformułowania „,postępowanie można umorzyć również przed wydaniem postanowienia o wszczęciu śledztwa lub dochodzenia" prowadzi do błędu logicznego, a mianowicie umorzenia nieistniejącego postępowania (Bojańczyk, Razowski 2011, 144). Nadto weryfikacja ziszczenia się przesłanek umożliwiających owo umorzenie wymaga już przeprowadzenia jakiegoś postępowania, a jednocześnie ocenić należy brak wystąpienia negatywnej przesłanki warunkującej dopuszczalność postępowania (art. $17 \mathrm{kpk}$ ) (Ustawa z 6 czerwca 1997 r. Kodeks postępowania...), zaś w przypadku jej wystąpienia obligatoryjnego niewszczynania lub umorzenia wszczętego postępowania karnego. 
Abstrahując od powyższego, gdyż przepis ten ma zastosowanie także i wówczas, gdy wszczęto już postępowanie, przesłankami zastosowania umorzenia postępowania są:

- nieznaczna ilość posiadanego (art. 62 ust. 1 lub ust. 3) narkotyku (środka odurzającego lub substancji psychotropowej) - jedna, dwie lub trzy porcje (dawki),

- przeznaczenie go na wlasny użytek sprawcy,

- niski stopień społecznej szkodliwości, aczkolwiek w stopniu większym niż znikomy,

- orzeczenie wobec sprawcy kary byłoby niecelowe ze względu na okoliczności popełnienia czynu.

Postępowanie będzie mogło być umorzone w przypadku wystąpienia wszystkich czterech okoliczności jednocześnie. Zastosowanie tego przepisu może mieć zastosowanie zarówno na etapie postępowania przygotowawczego, jak i jurysdykcyjnego. Orzeczenie o jego zastosowaniu wydaje się w formie postanowienia (także przez sąd), które ma charakter materialny (Gensikowski 2013, 226).

Nad wyraz istotne jest to, iż przyjęte rozwiązanie nie prowadzi do depenalizacji posiadania „narkotyków”. Nadal na gruncie ustawy o przeciwdziałaniu narkomanii posiadanie środków odurzających lub substancji psychotropowych, nawet w nieznacznej ilości i na własny użytek, pozostaje czynem zabronionym pod groźbą kary. Umorzenie z art. 62a NarkU ma charakter jedynie fakultatywny i jedynie w przypadku czynu przestępczego (niski, ale nie znikomy stopień społecznej szkodliwości czynu). Brak obligatoryjności, poprzez zapis ,postępowanie można umorzyć", wyłącza niejako automatyzm organu procesowego w zakresie merytorycznego rozstrzygnięcia danej sprawy. Umorzeniem postępowania organ procesowy stwierdza nie tylko fakt popełnienia czynu, ale także zawinienie sprawcy, którego przedmiotem jest zachowanie wyczerpujące znamiona z art. 62 ust. 1 lub 3 NarkU.

Jak wynika z uzasadnienia projektu ustawy dodającej art. 62a, w wielu sprawach, które w Polsce kończyły się wyrokami skazującymi, chodziło o ilości środków, które w innych krajach Unii Europejskiej są prawnie irrelewantne i umożliwiają stosowanie oportunizmu ścigania. Wydaje się zatem, iż wprowadzona zmiana korzystnie wpływa na walkę z przestępczością narkotykową, a to głównie poprzez zmniejszenie zaangażowania czasu, sił i środków Policji, prokuratury oraz sądów, a równocześnie może przynieść wbrew pozorom wiele korzyści z punktu widzenia zasadniczego celu stosowania represji karnej w obszarze przeciwdziałania narkomanii, tj. redukcji rozmiarów nielegalnej podaży środków odurzających i substancji psychotropowych (redukcja rozmiarów popytu to przede wszystkim, aczkolwiek nie wyłącznie, zadanie profilaktyki, leczenia, rehabilitacji i readaptacji) (Uzasadnienie rządowego projektu..., 12).

Mając na uwadze ratio legis wprowadzonego rozwiązania, podkreślić wypada, że wykazuje ono pozytywne praktyczne znaczenie. 
Prawomocnie skazani dorośli (w liczbach bezwzględnych) według rodzaju czynu oraz liczba umorzonych postępowań w trybie art. 62a NarkU według organu procesowego

\begin{tabular}{|c|c|c|c|c|}
\hline Rok & $\begin{array}{c}\text { Liczba skazanych } \\
\text { z ustawy }\end{array}$ & $\begin{array}{c}\text { Liczba skazanych } \\
\text { z art. 62 ust. 1-3 }\end{array}$ & $\begin{array}{c}\text { Liczba umorzeń } \\
\text { z art. 62a } \\
\text { Sądy rejonowe }\end{array}$ & $\begin{array}{c}\text { Liczba umorzeń } \\
\text { z art. 62a } \\
\text { Prokuratura }\end{array}$ \\
\hline 2011 & 19629 & 12451 & 0 & 0 \\
\hline 2012 & 17614 & 10949 & 162 & 2154 \\
\hline 2013 & 18096 & 11283 & 209 & 3132 \\
\hline 2014 & 17386 & 11214 & brak danych & 4273 \\
\hline
\end{tabular}

Źródło: opracowanie własne na podstawie danych statystycznych Ministerstwa Sprawiedliwości oraz obliczenia własne.

W tabeli 3 ujęto dane z sądów rejonowych, albowiem z uwagi na właściwość rzeczową, sądy okręgowe nie stosują instytucji umorzenia postępowania $z$ art. 62a NarkU - posiadanie substancji niedozwolonych jest występkiem. Uwzględniając, iż dane ujęto w liczbach bezwzględnych (osobach), należy zwrócić uwagę, iż w prokuraturach corocznie wzrasta liczba osób, wobec których oskarżyciel umorzył postępowanie w trybie art. 62a NarkU. Mimo tak krótkiego obowiązywania art. 62a NarkU w porządku prawnym, albowiem dodany ustawą nowelizacyjną wszedł w życie 9 grudnia 2011 r., wyraźna jest stała tendencja zwyżkowa - ok. 1000 osób rocznie.

Tabela 4

Liczba prawomocnie umorzonych postępowań w trybie art. 62a NarkU według organu procesowego w liczbach bezwzględnych (osobach)

\begin{tabular}{|c|c|c|c|c|}
\hline Rok & $\begin{array}{c}\text { Liczba umorzeń } \\
\text { z art. 62a } \\
\text { Sądy rejonowe }\end{array}$ & $\begin{array}{c}\text { Liczba umorzeń } \\
\text { z art. 62a } \\
\text { Prokuratura }\end{array}$ & $\begin{array}{c}\text { Suma umorzeń } \\
\text { Sądy + Prokuratura }\end{array}$ & Udział \% \\
\hline 2011 & 0 & 0 & 0 & 0,00 \\
\hline 2012 & 162 & 2154 & 2316 & 21,15 \\
\hline 2013 & 209 & 3132 & 3341 & 29,61 \\
\hline 2014 & brak danych & 4273 & 4273 & 38,10 \\
\hline
\end{tabular}

Źródło: opracowanie własne na podstawie danych statystycznych Ministerstwa Sprawiedliwości oraz obliczenia własne. 
Opisany powyżej stały wzrost liczby prawomocnych postanowień w przedmiocie umorzenia postępowania na podstawie art. 62a NarkU sięga ok. 9\% rocznie (piąta kolumna).

\section{PODSUMOWANIE}

Reasumując, należy pozytywnie ocenić wprowadzoną zmianę nowelizacyjną w zakresie dodania instytucji umorzenia z art. 62a i mimo dość krótkiego, gdyż trzyletniego okresu obowiązywania, skutki tej prawnokarnej reakcji na przestępczość narkotykową zdają się być już zauważalne. Ustawodawca zaostrzając zagrożenie ustawowe karą dla sprawców posiadających znaczne ilości substancji niedozwolonych w rozumieniu art. 62 ust. NarkU, poprzez podwyższenie dolnej granicy z 6 miesięcy do 1 roku pozbawienia wolności, a górnej granicy ustawowego zagrożenia z 8 do 10 lat, wprowadził jednocześnie instytucję umożliwiającą szybkie zakończenie postępowania wobec sprawców przestępstwa o znacznie mniejszej szkodliwości społecznej i to na podstawie suwerennej decyzji organu stosującego prawo (Zalewski 1999, 75), w tym na etapie postępowania przygotowawczego, bez konieczności kierowania sprawy do sądu. Orzekanie wobec sprawców uzależnionych od substancji psychoaktywnych, a więc chorych, podobnie jak wobec uzależnionych od alkoholu, kar izolacyjnych jest niecelowe i rodzi nieuzasadnione koszty utrzymywania skazanych w aresztach śledczych bądź zakładach karnych - na poziomie ok. 80 mln złotych rocznie (Kuźmicz, Mielecka-Kubień, Wiszejko-Wierzbicka 2009, 175). Penalizacja jakiejkolwiek ilości środków narkotycznych doprowadziła właśnie do wykrywania sprawców przestępstw z art. 62 ust. 1 lub 3 NarkU (por. tab. 2), a udaremniła organom ścigania wykrywanie sprawców wprowadzających do obrotu czy udostępniających (dilerów) zabronione substancje psychotropowe czy środki odurzające. Fakultatywna możliwość umorzenia postępowania po ziszczeniu się przesłanek z art. 62a NarkU ma w założeniu ustawodawcy zredukować popyt na środki narkotyczne (Uzasadnienie rządowego projektu..., 14). Niemniej winna oddziaływać na sprawcę prewencyjnie przede wszystkim poprzez uświadomienie mu, iż choć nie jest napiętnowany postępowaniem karnym, najpierw w prokuraturze, potem w sądzie, pozostając nadal osobą niekaraną, to zachowanie, którego się dopuścił, jest zabronione, wykrywane i ścigane, a z drugiej strony dana mu szansa $\mathrm{w}$ postaci umorzenia postępowania ma powstrzymać go od ponownego wejścia w konflikt z prawem. W ślad za dokonaną zmianą winny jednak zostać uruchomione odpowiednie działania edukacyjne, terapeutyczne i lecznicze. Wprowadzona instytucja niewątpliwie korzystnie wpływa na ekonomikę postępowania, które może zostać zakończone w początkowej fazie, a to odciąża organa ściągania, w szczególności sądy. 


\section{BIBLIOGRAFIA}

Bojańczyk, Antoni, Tomasz Razowski. 2011. „W sprawie nieprzekraczalnych granic semantyki”. Prokuratura i Prawo 11: 140-149.

Gensikowski, Piotr. 2013. „Procesowe aspekty stosowania instytucji przewidzianej w art. 62a ustawy o przeciwdziałaniu narkomanii”. Prokuratura i Prawo 7-8: 220-236.

Konarska-Wrzosek, Violetta. 1999. Ochrona dziecka w polskim prawie karnym. Toruń: Towarzystwo Naukowe Organizacji i Kierownictwa.

Krajewski, Krzysztof. 1998. „Prawnokarna problematyka nowej ustawy o przeciwdziałaniu narkomanii". Państwo i Prawo 4: 18-31.

Krajewski, Krzysztof. 1997. „Problematyka kryminalizacji posiadania środków odurzających i psychotropowych w świetle regulacji prawnomiędzynarodowych". Państwo i Prawo 1: 58-69.

Krajewski, Krzysztof. 2001. Sens i bezsens prohibicji. Prawo karne wobec narkotyków i narkomanii. Kraków: Zakamycze.

Krajewski, Krzysztof. 2008a. „Przestępstwo posiadania narkotyków oraz środki stosowane wobec jego sprawców w świetle badań aktowych”. Alkoholizm i Narkomania 3 (21): 221-234.

Krajewski, Krzysztof. 2008b. „Przestępstwo posiadania narkotyków w świetle badań aktowych”. Państwo i Prawo 9: 31-45.

Kuźmicz, Ewelina, Zofia Mielecka-Kubień, Dorota Wiszejko-Wierzbicka. 2009. Karanie za posiadanie. Art. 62 ustawy o przeciwdziałaniu narkomanii - koszt, czas, opinie. Warszawa: Fundacja Instytut Spraw Publicznych.

Lernell, Leszek. 1978. Zarys kryminologii ogólnej. Warszawa: Państwowe Wydawnictwo Naukowe.

Muszyńska, Anna. 2010. Opinia w przedmiocie rzadowego projektu o zmianie ustawy o przeciwdziałaniu narkomanii oraz niektórych innych ustaw (druk nr 3420) z dnia 17 listopada 2010 r. Wrocław: Biuro Analiz Sejmowych.

Nowak, Lucyna, Joanna Stańczyk, Agnieszka Znajewska. 2009. Ludność. Stan i struktura w przekroju terytorialnym (Stan w dniu 31 XII 2008 r.). Warszawa: Główny Urząd Statystyczny.

Ożóg, Marcin. 2012. „Zakaz marketingu tzw. dopalaczy. Uwagi na tle ostatnich zmian legislacyjnych”. W: Monika Namysłowska (red.). Reklama. Aspekty prawne. 332-346. Warszawa: Wolters Kluwer.

Płatek, Monika. 2011. Opinia do rzadowego projektu ustawy o zmianie ustawy o przeciwdziałaniu narkomanii oraz niektórych innych ustaw (druk nr 3420) z dnia 31 stycznia $2011 \mathrm{r}$. Warszawa: Biuro Analiz Sejmowych.

Sierosławski, Janusz. 2008. „Problem narkotyków i narkomanii w Polsce. Rozmiary i trendy zjawiska”. Serwis Informacyjny Narkomania 5(44): 58-66.

Srogosz, Tomasz. 2008. Ustawa o przeciwdziałaniu narkomanii. Komentarz. Warszawa: C.H. Beck.

Zalewski, Wojciech. 1999. „Charakter prawny tzw. umorzenia absorpcyjnego”. Przeglad Sadowy 6: 70-78. 


\title{
Adrian Bartha
}

\section{DISCONTINUANCE OF CRIMINAL PROCEEDINGS UNDER ART. 62A OF THE PREVENTION DRUG ABUSE ACT OF 29 JULY 2005 AS A POSITIVE MEASURE OF THE CRIMINAL AND LEGAL REACTION APPLIED AGAINST PERPETRATORS WHO ARE IN POSSESSION OF SOFT DRUGS IN A NEGLIGIBLE QUANTITY AND FOR PERSONAL USE}

\begin{abstract}
By the Act amendment of 1 April 2011, Art. 62a was incorporated into the original Act, which allows discontinuance of criminal proceedings before issuing an order to initiate an investigation or inquiry against a perpetrator in possession of psychotropic substances or intoxicants, including the case of lesser importance (Art. 62 (1 and 3) of the Act). A necessary condition is to establish that a verdict of a sentence would be pointless because of an offence circumstances and a degree of its social harmfulness. Also a person that is suspected of possession of drugs or psychotropic substances must have them in an insignificant quantity and only for personal use. This paper discusses some legal issues of the above described institution, which introduced a possibility of decriminalization of criminal liability of a perpetrator - a holder of drugs. The author also attempts to assess the effects of adding Art. 62a to the Act by presenting statistical data which illustrate the application of this institution by the prosecution and the criminal court in judicial decisions.

Keywords: drug abuse, discontinuance of proceedings, criminal sanction, preparatory and jurisdictional proceedings.
\end{abstract}

